\title{
Mental retardation and parental occupation: a study on the applicability of job exposure matrices
}

\author{
N Roeleveld, G A Zielhuis, F Gabreëls
}

\begin{abstract}
In a case-referent study on mental retardation and parental occupation, the applicability of job exposure matrices for the identification of risk factors was evaluated. The parents of $\mathbf{3 0 6}$ mentally retarded children (cases) and 322 referents were interviewed about their occupational activities in the pregnancy period. Detailed occupational histories were obtained that were compared with exposures generated by two different job exposure matrices. The agreement between interview and matrices was low: the sensitivity ranged from $17.9 \%$ to $32.4 \%$ and the percentages of false positive exposures from $66 \cdot 7 \%$ to $96.0 \%$. By means of the interview, significantly increased odds ratios (ORs) were found for exposure of the mother in late pregnancy to radiation $(O R=$ 9.3), mercury $(O R=8 \cdot 7)$, organic solvents $(O R=1 \cdot 7)$, hair cosmetics and dyes $(O R=$ $3 \cdot 7)$, paint $(\mathrm{OR}=2 \cdot 7)$, hexachlorophenel phenylphenol $(O R=3 \cdot 1)$, antibiotics (OR = $2 \cdot 9)$, and dust $(O R=2 \cdot 2)$ and for working with copying machines $(O R=3 \cdot 0)$ or in occupations with poor climatological circumstances and permanent contact with people. The last was confirmed by the British matrix (OR = 1.7). Otherwise, most of the mentioned associations were missed by the job exposure matrices. Therefore, these matrices were not considered to be applicable in this particular study, nor in most other reproductive epidemiological studies in view of their general properties and limitations.
\end{abstract}

(British Fournal of Industrial Medicine 1993;50:945-954)

Department of Medical Informatics and Epidemiology, University of Nijmegen, The Netherlands N Roeleveld, G A Zielhuis

Department of Child Neurology, University Hospital Nijmegen, The Netherlands

F Gabreëls
In occupational epidemiological studies, several methods can be used to gather information about exposure retrospectively. ${ }^{1}$ Personal occupational histories, either obtained by means of postal questionnaires or through face to face or telephone interviews, may supply detailed information on all exposure factors under study for each participant. A serious disadvantage, however, is the presumed occurrence of recall bias. ${ }^{2-4}$ Company registers usually contain accurately recorded occupational titles, but are incomplete for individual exposure. ${ }^{1}$ Job exposure matrices, finally, can be used to generate a list of (potential) occupational exposures for each study subject when the occupational title and industrial category are known. ${ }^{56}$ Several drawbacks in the coding of occupations and in the classification of exposures limit the applicability of these matrices, however. ${ }^{5} 7$

In a case-referent study on mental retardation and parental occupation, detailed information on exposure was collected by means of personal interviews with the parents. Mental retardation is a developmental defect of the central nervous system with a prevalence of about $3 \%$ in school age children; the causes include several genetic and pre, peri, and postnatal factors. ${ }^{8}$ The interview focused on the hypothesised exogenic risk factors for mental retardation, ${ }^{910}$ such as parental exposure to lead, ${ }^{11,12}$ methylmercury, ${ }^{1314}$ alcohol and other organic solvents, ${ }^{1015}$ and ionising radiation. ${ }^{16}{ }^{17}$ Other potentially hazardous occupational and nonoccupational exposures were also taken into account. As a result of this study, several agents could be indicated as possible occupational risk factors for mental retardation in offspring.

As the personal interview is a time consuming and expensive method for data collection on occupational exposure, we were interested to find out whether the same or even better results could be obtained more efficiently. Therefore, we compared the exposure data generated by a British ${ }^{5}$ and an American ${ }^{6}$ job exposure matrix to those from the personal interview with the parents, to evaluate the accuracy of the matrices for identification of risk factors for mental retardation. The applicability of job exposure matrices for reproductive 
epidemiological studies in general was inferred from the results of the present study.

\section{Study population and methods}

A case-referent study was conducted on 340 mentally retarded children with unknown aetiology (cases) and 362 children with other congenital handicaps, for which the cause was known (referents). Both groups were selected from the medical files of children referred to the paediatric or child neurology departments of the Nijmegen University Hospital or to rehabilitation centres in the vicinity, in the period from 1979 up to and including 1987. The diagnoses of the cases included mental and psychomotor retardation (International Classification of Diseases (ICD) codes 317-319) with an IQ $<80$, according to the Dutch school criterion for the mentally retarded. Thorough aetiological examination in the past had not revealed a specific cause for the retardation. Thus the pre, peri, and neonatal development of the cases was practically uneventful and genetic or other disorders were ruled out. The main diagnoses of the referents were familial neuromuscular and metabolic disorders (ICD $334 \cdot 1,335$, and $359 \cdot 1$ ) and cerebral palsy (ICD 343). Genetic factors $(45 \cdot 4 \%)$ and severe complications at birth $(41.6 \%)$, neither of which were associated with the parental occupation, were the predominant causes for the congenital defects among the referents. To avoid information bias this referent group was chosen for its comparability with the case group on relevant characteristics, such as the geographical area, the availability of medical services, and the emotional impact that the birth and upbringing of a handicapped child had on the parents.

\section{DATA COLLECTION THROUGH INTERVIEW}

The parents of cases and referents were invited by letter to participate in a personal interview about the "critical period" that ranged from three months preconception to six months postnatally for the child of interest. The total period was subdivided into five intervals according to the stages of development (preconception period, pregnancy months $1-2$, pregnancy months $3-5$, pregnancy months $6-9$, postnatal period). The interviews were performed by two trained interviewers with a structured questionnaire. Firstly, a calendar was filled in with outstanding events to focus the attention of the parents on the critical period. Next, a detailed occupational history was made for both parents for each time interval, based on questions about occupational title, industrial category, and physical working environment, supplemented by industry specific exposure checklists. These checklists included all the chemical substances that were possibly used in the particular industrial group to which the respondent's job belonged. ${ }^{4}$ The interview was completed with questions about the age and education of the parents, occupational exposure in the past, place of residence, smoking and drinking habits, consumption of medical drugs, and leisure time activities and exposures.

\section{ANALYSES OF INTERVIEW INFORMATION}

The data were coded by an occupational hygienist who was blinded towards case or referent category, and statistically analysed per time interval by means of cross tabulation and logistic regression modelling. As effect measures, odds ratios (ORs) were calculated with $90 \%$ confidence intervals $(90 \%$ CIs), because of the exploratory character of the study. Where necessary, the ORs were adjusted for confounding. To check for potential confounding variables, the distributions of background and anamnestic variables, lifestyle factors, and leisure time activities were examined (table 1). The occupational titles were grouped according to the classification of occupations of the International Labour Office $^{18}$ and analysed with the unemployed parents as reference category (table 2). Parents who had been employed for at least two weeks in a certain time interval were counted among the working population for that interval. The unemployed

Table 1 Distribution of confounding variables of the mother in the analyses of occupational exposures in different intervals during the critical period

\begin{tabular}{|c|c|c|c|}
\hline Confounding variables of mother & $\begin{array}{l}\text { Interval } \\
\text { for correction } \\
\text { of confounding }\end{array}$ & $\begin{array}{l}\text { Cases }(\%) \\
(n=306)\end{array}$ & $\begin{array}{l}\text { Referents (\%) } \\
(n=322)\end{array}$ \\
\hline $\begin{array}{l}\text { Gravidity: primigravidae } \\
\text { Complications during pregnancy } \\
\text { Premature birth ( }<38 \mathrm{wk} \text { ) } \\
\text { Consumption of alcoholic drinks } \\
\text { Leisure time activities: }\end{array}$ & $\begin{array}{l}\text { Total period } \\
\text { Months 3-5 } \\
\text { Months 6-9 } \\
\text { Months 3-9 }\end{array}$ & $\begin{array}{l}36 \cdot 6 \\
14 \cdot 1 \\
12 \cdot 1 \\
39 \cdot 3\end{array}$ & $\begin{array}{l}46 \cdot 0 \\
19 \cdot 6 \\
25 \cdot 8 \\
31 \cdot 4\end{array}$ \\
\hline $\begin{array}{l}\text { Cleaning of the house } \\
\text { Painting of the house } \\
\text { Working in the garden } \\
\text { Outdoor (exhaust fumes) }\end{array}$ & $\begin{array}{l}\text { Total period } \\
\text { Months } 3-5 \\
\text { Total period } \\
\text { Total period }\end{array}$ & $\begin{array}{l}86 \cdot 0 \\
16 \cdot 3 \\
26 \cdot 5 \\
38 \cdot 9\end{array}$ & $\begin{array}{l}76 \cdot 6 \\
11 \cdot 5 \\
19 \cdot 6 \\
31 \cdot 4\end{array}$ \\
\hline
\end{tabular}


Table 2 Associations between mental retardation and occupation of the mother in late pregnancy (months 6-9)

\begin{tabular}{|c|c|c|c|c|c|}
\hline $\begin{array}{l}\text { Occupation of mother } \\
\text { in late pregnancy }\end{array}$ & $\begin{array}{l}\text { Cases } \\
(N=306)\end{array}$ & $\begin{array}{l}\text { Referents } \\
(N=315)\end{array}$ & $O R$ & $O R_{\text {adj }}{ }^{*}$ & $(90 \% C I)$ \\
\hline $\begin{array}{l}\text { Occupationally employed } \\
\text { Health care workers } \\
\text { Nurses } \\
\text { Other medical workers } \\
\text { Educational workers } \\
\text { Clerical workers } \\
\text { Bookkeepers/cashiers } \\
\text { Other clerical workers } \\
\text { Sales workers } \\
\text { Service workers } \\
\text { Hairdressers } \\
\text { Housekeepers } \\
\text { Catering services } \\
\text { Agricultural workers } \\
\text { Industrial workers } \\
\text { Textile industry } \\
\text { Other industries }\end{array}$ & $\begin{array}{r}106 \\
24 \\
19 \\
5 \\
9 \\
23 \\
7 \\
16 \\
8 \\
17 \\
4 \\
11 \\
2 \\
14 \\
11 \\
7 \\
4\end{array}$ & $\begin{array}{r}94 \\
12 \\
7 \\
5 \\
6 \\
22 \\
3 \\
19 \\
11 \\
19 \\
2 \\
11 \\
6 \\
16 \\
8 \\
4 \\
4\end{array}$ & $\begin{array}{l}1 \cdot 3 \\
2 \cdot 2 \\
3 \cdot 0 \\
1 \cdot 1 \\
1 \cdot 7 \\
1 \cdot 2 \\
2 \cdot 6 \\
0 \cdot 9 \\
0 \cdot 8 \\
1 \cdot 0 \\
2 \cdot 2 \\
1 \cdot 1 \\
0 \cdot 4 \\
1 \cdot 0 \\
1 \cdot 5 \\
1 \cdot 9 \\
1 \cdot 1\end{array}$ & $\begin{array}{l}1 \cdot 6 \\
3 \cdot 1 \\
4 \cdot 2 \\
1.6 \\
2 \cdot 6 \\
1.8 \\
5 \cdot 7 \\
1.4 \\
0 \cdot 9 \\
1 \cdot 2 \\
2 \cdot 7 \\
1 \cdot 5 \\
0 \cdot 3 \\
1 \cdot 0 \\
1 \cdot 8 \\
2 \cdot 7 \\
1 \cdot 2\end{array}$ & $\begin{array}{l}(1 \cdot 2-2 \cdot 2) \\
(1 \cdot 6-5 \cdot 8) \\
(1 \cdot 9-9 \cdot 2) \\
(0 \cdot 5-4 \cdot 9) \\
(1 \cdot 0-6 \cdot 5) \\
(1 \cdot 0-3 \cdot 2) \\
(1 \cdot 6-20 \cdot 1) \\
(0 \cdot 7-2 \cdot 6) \\
(0 \cdot 4-2 \cdot 0) \\
(0 \cdot 7-2 \cdot 2) \\
(0 \cdot 6-11 \cdot 5) \\
(0 \cdot 7-3 \cdot 2) \\
(0 \cdot 1-1 \cdot 4) \\
(0.5-2 \cdot 0) \\
(0.8-4 \cdot 3) \\
(0.9-8 \cdot 3) \\
(0.3-4 \cdot 0)\end{array}$ \\
\hline
\end{tabular}

*Odds ratios adjusted for primigravidity, prematurity, alcohol consumption, and leisure time activities (cleaning at home, gardening, outdoor activities)

parents were not considered to have been occupationally exposed; any exposure at home was recorded under leisure time exposure and treated as a potential confounder. The occupational exposures were analysed as dichotomous variables, contrasting parents who had and who had not been exposed to a particular factor according to the interview. To avoid unstable estimates, substances to which less than $1 \%$ of the population had been exposed were excluded from the analyses; if possible, clusters of exposures were used instead.

\section{JOB EXPOSURE MATRICES}

The information on occupational title and industrial category from the interviews was recoded according to the British Registrar General's classifications of occupations and industries for the British matrix ${ }^{5}$ and converted into a special five digit code used in the American matrix. ${ }^{6}$ Exposures were generated for each parent who had been employed in the critical period (308 mothers and 611 fathers). In the British job exposure matrix, a distinction was made between exposures before and after 1950; the last were used in the present study. Forty nine exposure categories were included in this matrix, but only 30 of these were comparable with (groups of) exposures inquired about in the interview. Of the 367 exposure items in the American job exposure matrix, 42 could be matched with the interview and were taken into account in the analyses. A dichotomous yes or no variable was created for each exposure, irrespective of the level of exposure.

For each parent, the exposures generated by the matrices were compared with the exposures reported in the interview for the preconception period, in which time interval the number of exposed parents reached a maximum. As measures of agreement, the number of concordant and discordant exposures were calculated. These measures were then averaged across the 308 mothers and 611 fathers (table 3). Setting the interview as a gold standard, the sensitivity and the percentage of false positive exposures were also calculated for each matrix. Furthermore, the exposures from the matrices were analysed in the same way as the interview data for each time interval in the critical period. The ORs

Table 3 Agreement between occupational exposures reported in the personal interview and those generated by the British and American job exposure matrices 56

\begin{tabular}{|c|c|c|c|c|}
\hline \multirow[b]{3}{*}{$\begin{array}{l}\text { Measures of agreement } \\
\text { between personal } \\
\text { interview and matrix }\end{array}$} & \multicolumn{4}{|c|}{ Average number of exposures } \\
\hline & \multicolumn{2}{|c|}{$\begin{array}{l}\text { British job exposure matrix } \\
\text { ( } 30 \text { matching exposures) }\end{array}$} & \multicolumn{2}{|c|}{$\begin{array}{l}\text { American job exposure matrix } \\
\text { (42 matching exposures) }\end{array}$} \\
\hline & $\begin{array}{l}\text { Mother } \\
(n=308)\end{array}$ & $\begin{array}{l}\text { Father } \\
(n=611)\end{array}$ & $\begin{array}{l}\text { Mother } \\
(n=308)\end{array}$ & $\begin{array}{l}\text { Father } \\
(n=611)\end{array}$ \\
\hline Concordant exposures: & & & & \\
\hline $\begin{array}{l}\text { Interview }+ \text { /matrix }+ \\
\text { Interview }- \text { /matrix }-\end{array}$ & $\begin{array}{r}0 \cdot 3 \\
27 \cdot 2\end{array}$ & $\begin{array}{r}1 \cdot 0 \\
24 \cdot 7\end{array}$ & $\begin{array}{r}0 \cdot 2 \\
35 \cdot 8\end{array}$ & $\begin{array}{r}1 \cdot 1 \\
32 \cdot 9\end{array}$ \\
\hline $\begin{array}{l}\text { Discordant exposures: } \\
\text { Interview + /matrix- } \\
\text { Interview-/matrix + }\end{array}$ & $\begin{array}{l}0.9 \\
1.6\end{array}$ & $\begin{array}{l}2 \cdot 2 \\
2 \cdot 1\end{array}$ & $\begin{array}{l}1 \cdot 0 \\
5 \cdot 0\end{array}$ & $\begin{array}{l}2 \cdot 8 \\
5 \cdot 2\end{array}$ \\
\hline $\begin{array}{l}\text { Sensitivity of matrix } \\
\text { False positive exposures }\end{array}$ & $\begin{array}{l}26 \cdot 8 \% \\
83 \cdot 1 \%\end{array}$ & $\begin{array}{l}32 \cdot 4 \% \\
66 \cdot 7 \%\end{array}$ & $\begin{array}{l}17 \cdot 9 \% \\
96.0 \%\end{array}$ & $\begin{array}{l}29 \cdot 3 \% \\
82 \cdot 0 \%\end{array}$ \\
\hline
\end{tabular}


were derived for all the agents in the British matrix and for the 42 American exposure items that matched the interview. The number of exposed parents per exposure item and the ORs were compared with the results from the personal interview.

\section{Results}

The parents of 306 cases and 322 referents participated in the study (overall response $89.5 \%$ ). For $56.9 \%$ of the cases and $47 \cdot 2 \%$ of the referents, both parents were interviewed personally; in the other events, the mother supplied information about the father and the appropriate exposure checklists were left for him to complete. The lag time between the critical period and the interview varied from two to 25 years with an average lag time of 10.7 years. Consistency checks showed that the quality and completeness of the interview information was satisfactory for most of the participants.

\section{CONFOUNDING VARIABLES}

The distributions of the potential confounding variables are described in detail elsewhere. ${ }^{19}$ For the fathers, none of these variables acted as confounders. Table 1 lists the confounding variables corrected for in the analyses of the mothers. Cases and referents were comparable with respect to sex, age, and education of the parents, place of residence, and housing conditions, but due to the selection of the referent group some anamnestic variables were preponderant among the referents. Of these, only primigravidity proved to be a strong confounder, as more primigravidae tend to have a job than mothers with children. Also, adjustment for complications during pregnancy (months 3-5) and prematurity (months 6-9) was required, as these factors could form a reason to stop working early in pregnancy. Seven referent mothers who had epilepsy were excluded from the analyses.

Among the lifestyle factors, ${ }^{19}$ alcohol consumption was significantly more prevalent in case mothers and proved to be a confounder during the fetal period (pregnancy months 3-5 and 6-9). During each time interval, a significantly higher proportion of case mothers were involved in cleaning at home, gardening, and outdoor activities in which they inhaled exhaust fumes. These leisure time activities were included in the further analyses as confounding variables, as was painting at home in pregnancy during months 3-5. Other leisure time activities or exposures did not confound the results.

\section{OCCUPATIONAL TITLES}

As an indication of the occupational distribution among cases and referents, table 2 lists the maternal occupations for the late pregnancy period (months 6-9). During this interval, $34 \cdot 6 \%$ of the case mothers and $29.8 \%$ of the referent mothers were still employed, as opposed to $47.0 \%$ and $50.3 \%$ preconception. Increased risks were found for health care workers $(O R=3 \cdot 1)$, educational workers $(\mathrm{OR}=2 \cdot 6)$, bookkeepers/cashiers (OR = $5 \cdot 7)$, hairdressers $(\mathrm{OR}=2 \cdot 7)$, and workers in the textile industry $(O R=2 \cdot 7)$. In the preconception period and the first five months of pregnancy, the same associations were seen but these were only statistically significant for hairdressers $\left(\mathrm{OR}_{\text {month } 3-5}=\right.$ $4 \cdot 3,90 \% \mathrm{CI} 1 \cdot 1-16 \cdot 7)$ and cashiers $\left(\mathrm{OR}_{\text {months } 3-5}=\right.$ $3.9,90 \%$ CI $1 \cdot 2-12 \cdot 9)$. The number of women who started working again after pregnancy was too small to calculate ORs for the maternal occupation in the postnatal period. No differences were found in the occupational distribution of case and referent fathers.

\section{AGREEMENT BETWEEN INTERVIEW AND MATRICES}

Table 3 shows the average number of concordant and discordant exposures presented as measures of agreement between the interview and job exposure matrices. Most exposures were neither reported in the interview, nor generated by the matrices (interview-/matrix-). Only $9 \cdot 3 \%$ and $17 \cdot 7 \%$ of the exposures scored positively in the interview or British matrix for mothers and fathers respectively. These figures were $14 \cdot 8 \%$ and $21 \cdot 7 \%$ for the American matrix. The number of concordant exposures (interview + /matrix + ) was small compared with the discordant exposures. For instance, for the fathers, the American matrix generated an average of only one exposure in accordance with the interview, whereas almost three self reported exposures were missed and five extra exposures were given. The large number of reported exposures that were missed by the job exposure matrices (interview + /matrix-) led to low sensitivities, varying from $17.9 \%$ for mothers in the American matrix to $32.4 \%$ for fathers in the British matrix. The percentages of false positive exposures ranged from $66.7 \%$ to $96.0 \%$ due to the high frequency of matrix exposures that were not reported by the parents (interview-/matrix + ). On average, the parents were exposed to twice as many agents according to the matrices than were recorded during the interview. These differences were strongest for mothers in the American job exposure matrix.

\section{OCCUPATIONAL EXPOSURE OF THE MOTHER}

Tables 4-6 summarise the results of the analyses for the mothers for the late pregnancy period (months 6-9). During this interval, the most pronounced associations were found. No ORs were calculated for agents to which less than $1 \%$ of the population were exposed; if exposure was below 
Table 4 Associations between mental retardation and maternal occupational exposures in late pregnancy (months 6-9) according to information gathered by means of a personal interview or generated by the British job exposure matrix $(n=49 /$ matching exposures $n=30)$

\begin{tabular}{|c|c|c|c|c|c|c|c|c|}
\hline \multirow{2}{*}{$\begin{array}{l}\text { Occupational exposure } \\
\text { of the mother in late } \\
\text { pregnancy (months 6-9) }\end{array}$} & \multicolumn{4}{|c|}{ Personal interview } & \multicolumn{4}{|c|}{ British job exposure matrix } \\
\hline & Cases & Referents & $O R^{*}$ & $(90 \% C I)$ & Cases & Referents & $O R^{*}$ & $(90 \% \mathrm{CI})$ \\
\hline $\begin{array}{l}\text { Ionising radiation } \\
\text { Ultraviolet light } \\
\text { Heat } \\
\text { Cold } \\
\text { Lead (compounds) } \\
\text { Mercury (compounds) } \\
\text { Arsenic (compounds) } \\
\text { Organic solvents } \\
\text { Diesel fuel } \\
\text { PAHs (skin contact) } \\
\text { Aromatic amines† } \\
\text { Chlorophenols† } \\
\text { Polychlorinated biphenyls† } \\
\text { Nitrates† } \\
\text { Formaldehyde } \\
\text { Ethylene oxide } \\
\text { Paint/pigments/dyes } \\
\text { Printing inks } \\
\text { Adhesives } \\
\text { Waxes and polishes† } \\
\text { Detergents } \\
\text { Herbicides } \\
\text { Biologically active dust } \\
\text { Dust (wood/textile/coal) } \\
\text { Contact with animalst } \\
\text { Contact with public } \\
\text { Outdoor occupation† }\end{array}$ & $\begin{array}{r}32 \\
11 \\
6 \\
27\end{array}$ & $\begin{array}{r}24 \\
11 \\
1 \\
19\end{array}$ & $\begin{array}{l}\bar{Z} \\
2 \cdot 7 \\
\bar{Z} \\
\overline{1} \\
1 \cdot 5 \\
1 \cdot 0 \\
0 \cdot 8 \\
2 \cdot 2\end{array}$ & $\begin{array}{l}(1.0-2 \cdot 8) \\
(0.6-2 \cdot 5) \\
(1.4-53 \cdot 3) \\
(1.0-2.8)\end{array}$ & $\begin{array}{r}10 \\
6 \\
3 \\
17 \\
2 \\
6 \\
18 \\
\\
13 \\
4 \\
5 \\
12 \\
22 \\
14 \\
3 \\
10 \\
7 \\
22 \\
25 \\
16 \\
15 \\
14 \\
14 \\
7 \\
14 \\
54 \\
16\end{array}$ & $\begin{array}{r}5 \\
6 \\
9 \\
17 \\
6 \\
7 \\
78 \\
18 \\
13 \\
5 \\
2 \\
12 \\
20 \\
16 \\
5 \\
6 \\
2 \\
20 \\
21 \\
13 \\
18 \\
16 \\
17 \\
5 \\
19 \\
42 \\
16\end{array}$ & $\begin{array}{l}2.2 \\
1.3 \\
0.3 \\
1.0 \\
0.4 \\
1.0 \\
1.1 \\
1.0 \\
1.1 \\
2.6 \\
1.0 \\
1.6 \\
0.9 \\
0.8 \\
1.8 \\
3.9 \\
1.6 \\
1.6 \\
1.4 \\
0.9 \\
0.9 \\
0.9 \\
1.4 \\
0.7 \\
1.7 \\
1.1\end{array}$ & $\begin{array}{l}(0.8-5.5) \\
(0.5-3.4) \\
(0.1-1.1) \\
(0.6-1.9) \\
(0.1-1.7) \\
(0.4-2.7) \\
(0.6-1.9) \\
(0.5-2.0) \\
(0.3-3.4) \\
(0.6-10.5) \\
(0.5-2.0) \\
(0.9-2.8) \\
(0.5-1.7) \\
(0.2-2.8) \\
(0.8-4.5) \\
(1.0-15.1) \\
(0.9-2.8) \\
(0.9-2.8) \\
(0.7-2.7) \\
(0.5-1.6) \\
(0.5-1.7) \\
(0.5-1.6) \\
(0.5-3.8) \\
(0.4-1.4) \\
(1.2-2.5) \\
(0.6-2.1)\end{array}$ \\
\hline
\end{tabular}

*Odds ratios adjusted for primigravidity, prematurity, alcohol consumption, and leisure time activities (cleaning at home, gardening, outdoor activities)

†Exposure not asked for in the personal interview

$1 \%$ in the interview and matrix, the agent was omitted from the tables. For most exposures, the matrices assigned many more mothers to the exposed category than the interview.

Among the 30 exposures that matched between the interview and British job exposure matrix (table 4), significantly increased ORs were found by the interview method for exposure to heat $(O R=1 \cdot 7)$, mercury $(O R=8 \cdot 7)$, organic solvents $(O R=1 \cdot 7)$, paint, pigments and dyes $(O R=2 \cdot 7)$, and dust $(O R=2 \cdot 2)$. By contrast, the matrix showed a reduced $O R$ for heat $(O R=0.3)$, ORs of about unity for mercury and dust, and almost no exposure to solvents. The number of exposed mothers and the ORs were comparable only for paint $\left(O R_{\text {marix }}=3 \cdot 9\right)$. For ionising radiation, ethylene oxide, printing inks and adhesives, the matrix produced a number of exposed persons and slightly increased ORs, whereas according to the interview almost no mothers were exposed. Examination of the non-matching exposure items of the British matrix resulted in an interesting finding for the exposure variable "contact with public" $(\mathrm{OR}=1 \cdot 7$, $90 \%$ CI $1 \cdot 2-2 \cdot 5$ ).

In the comparison between the interview and American job exposure matrix (table 5), the same differences were seen for the ORs of mercury (OR $=8.7 v 1.2)$ and dust $(\mathrm{OR}=2.2 v 1.3)$. The $\mathrm{OR}$ for heat was 0.9 in the American matrix and for paint no matrix OR could be calculated. Many other exposures belonged to the extremely low exposure categories in the interview, whereas the matrix showed a considerable number of exposed mothers. The ORs for aluminum/magnesium (OR $=1 \cdot 8)$, diesel fuel $(O R=2 \cdot 0)$, chloroform $(O R=$ $1.9)$, and methylene chloride $(O R=2 \cdot 7)$ were slightly increased, but were only statistically significant for diesel fuel. In the interview data, on the other hand, significantly increased ORs were found for vibration (OR $=2.9$ ) and exposure to alcohol $(O R=1.9)$, without any comparable associations being found by means of the job exposure matrix.

Table 6 lists the remaining exposure categories of the interview. These exposures were not included in either one of the job exposure matrices, but were relevant to the study on mental retardation. A series of appreciably increased risks were foundnamely, working with copying machines (OR = $3.0)$ or in a draughty environment $(O R=1.9)$ and occupational exposure to (non)-ionising radiation $(\mathrm{OR}=9 \cdot 3)$, hair cosmetics and dyes $(\mathrm{OR}=3 \cdot 7)$, hexachlorophene/phenylphenol $(\mathrm{OR}=3 \cdot 1)$, and antibiotics $(\mathrm{OR}=2 \cdot 9)$.

Similar to the late pregnancy period (months 6-9), significantly increased ORs were found in the preconception period and in early and mid-preg- 
Table 5 Associations between mental retardation and maternal occupational exposures in late pregnancy (months 6-9) according to information gathered by means of a personal interview or generated by the American job exposure matrix ${ }^{6}$ (matching exposures $n=42$ )

\begin{tabular}{|c|c|c|c|c|c|c|c|c|}
\hline \multirow{2}{*}{$\begin{array}{l}\text { Occupational exposure } \\
\text { of the mother in late } \\
\text { pregnancy (months 6-9) }\end{array}$} & \multicolumn{4}{|c|}{ Personal interview } & \multicolumn{4}{|c|}{ American job exposure matrix } \\
\hline & Cases & Referents & $O R^{*}$ & $(90 \% \mathrm{CI})$ & Cases & Referents & $O R^{*}$ & $(90 \% C I)$ \\
\hline $\begin{array}{l}\text { Ionising radiation } \\
\text { Ultraviolet light }\end{array}$ & - & & & & $\begin{array}{l}14 \\
26\end{array}$ & $\begin{array}{l}13 \\
22\end{array}$ & $\begin{array}{l}1 \cdot 4 \\
1 \cdot 3\end{array}$ & $\begin{array}{l}(0 \cdot 7-2 \cdot 7) \\
(0 \cdot 8-2 \cdot 2)\end{array}$ \\
\hline Vibration & 11 & 4 & $2 \cdot 9$ & $(1 \cdot 1-7 \cdot 9)$ & & & - & \\
\hline Heat & 32 & 24 & $1 \cdot 7$ & $(1 \cdot 0-2 \cdot 8)$ & 4 & 6 & 0.9 & $(0 \cdot 3-2 \cdot 6)$ \\
\hline Cold & 11 & 11 & $1 \cdot 2$ & $(0 \cdot 6-2 \cdot 5)$ & 4 & 5 & $1 \cdot 0$ & $(0.3-3.2)$ \\
\hline Lead (compounds) & & & - & & 9 & 9 & $1 \cdot 1$ & $(0.5-2 \cdot 6)$ \\
\hline Mercury (compounds) & 6 & 1 & $8 \cdot 7$ & $(1 \cdot 4-53 \cdot 3)$ & 15 & 14 & $1 \cdot 2$ & $(0.7-2 \cdot 4)$ \\
\hline Iron/zinc (compounds) & & & - & & 16 & 13 & $1 \cdot 4$ & $(0 \cdot 7-2 \cdot 6)$ \\
\hline \multicolumn{9}{|l|}{ Aluminum/magnesium } \\
\hline (compounds) & & & - & & 18 & 11 & $1 \cdot 8$ & $(0.9-3.6)$ \\
\hline Welding fumes & & & - & & 13 & 10 & $1 \cdot 5$ & $(0.7-3 \cdot 1)$ \\
\hline Gasoline/petroleum & & & - & & 10 & 10 & $1 \cdot 1$ & $(0.5-2 \cdot 3)$ \\
\hline Antiknock agents & & & - & & 11 & 10 & $1 \cdot 3$ & $(0.6-2 \cdot 9)$ \\
\hline Diesel fuel & & & - & & 15 & 10 & $2 \cdot 0$ & $(1 \cdot 0-4 \cdot 1)$ \\
\hline Coal tar & & & - & & 18 & 17 & $1 \cdot 1$ & $(0 \cdot 6-2 \cdot 0)$ \\
\hline Benzene/toluene/xylene & & & - & & 25 & 26 & $1 \cdot 1$ & $(0.7-1 \cdot 8)$ \\
\hline Chloroform & & & - & & 7 & 4 & $1 \cdot 9$ & $(0 \cdot 7-5 \cdot 7)$ \\
\hline Methylene chloride & & & - & & 7 & 3 & $2 \cdot 7$ & $(0.8-8 \cdot 7)$ \\
\hline Triperchloroethylene & & & - & & 19 & 16 & 1.4 & $(0.8-2.5)$ \\
\hline Alcohol & 19 & 12 & 1.9 & $(1 \cdot 0-3 \cdot 5)$ & 5 & 7 & 0.8 & $(0 \cdot 3-2 \cdot 1)$ \\
\hline Formaldehyde & & & - & & 13 & 10 & $1 \cdot 4$ & $(0 \cdot 7-3 \cdot 0)$ \\
\hline Ethylene oxide & & & - & & 9 & 10 & $1 \cdot 0$ & $(0.5-2 \cdot 1)$ \\
\hline Paint/pigments/dyes & 9 & 4 & $2 \cdot 7$ & $(1 \cdot 0-7 \cdot 5)$ & & & - & \\
\hline Pesticides & 5 & 6 & $1 \cdot 0$ & $(0 \cdot 4-2 \cdot 8)$ & 26 & 22 & $1 \cdot 3$ & $(0.8-2 \cdot 2)$ \\
\hline Dust (wood/textile/coal) & 14 & 7 & $2 \cdot 2$ & $(1 \cdot 0-5 \cdot 0)$ & 37 & 31 & $1 \cdot 3$ & $(0.9-2 \cdot 1)$ \\
\hline Butadiene/styrene/chloroprene & & & - & & 9 & 10 & $1 \cdot 0$ & $(0 \cdot 5-2 \cdot 2)$ \\
\hline Epoxy resins & & & - & & 20 & 16 & $1 \cdot 5$ & $(0 \cdot 8-2 \cdot 7)$ \\
\hline
\end{tabular}

*Odds ratios adjusted for primigravidity, prematurity, alcohol consumption, and leisure time activities (cleaning at home, gardening, outdoor activities)

nancy (months 1-2 and 3-5) According to the interview, the ORs were increased for mothers working with copying machines or exposed to (non)-ionising radiation, mercury, and hair cosmetics and dyes. The British job exposure matrix showed increased ORs for paint and the American matrix for vibration. In the postnatal period the number of exposed mothers was too small to perform meaningful analyses.
OCCUPATIONAL EXPOSURE OF THE FATHER

Tables 7 and 8 summarise the results for the father for the preconception period, which is indicative of the total critical period. In general, the number of fathers exposed to a particular agent was high compared with the mothers. The ORs could be calculated for almost all exposure categories, but most of them varied around unity. For the sake of parsimony, exposures were

Table 6 Associations between mental retardation and maternal occupational exposures in late pregnancy (months 6-9) according to information gathered by means of a personal interview not generated by the British or American job exposure matrices ${ }^{5}$

\begin{tabular}{|c|c|c|c|c|}
\hline $\begin{array}{l}\text { Occupational exposure of } \\
\text { mother in late pregnancy }\end{array}$ & $\frac{\text { Caces }}{(n=306)}$ & $\begin{array}{l}\text { Referents } \\
(n=315)\end{array}$ & $O R_{a d j}$ * & $(90 \% C I)$ \\
\hline $\begin{array}{l}\text { Correction fluid } \\
\text { Copying machines } \\
\text { Computers (personal) } \\
\text { Draughty environment } \\
\text { Lack of fresh air } \\
\text { Noisy environment } \\
\text { (Non)-ionising radiation } \\
\text { Hair cosmetics/dyes } \\
\text { Hexachlorophene/phenylphenol } \\
\text { Antibiotics } \\
\text { Other medical drugs } \\
\text { Animal food }\end{array}$ & $\begin{array}{r}13 \\
14 \\
3 \\
20 \\
30 \\
18 \\
7 \\
6 \\
8 \\
12 \\
6 \\
7\end{array}$ & $\begin{array}{r}11 \\
6 \\
5 \\
12 \\
23 \\
12 \\
1 \\
2 \\
3 \\
5 \\
5 \\
6\end{array}$ & $\begin{array}{l}1 \cdot 7 \\
3 \cdot 0 \\
0 \cdot 7 \\
1 \cdot 9 \\
1 \cdot 5 \\
1 \cdot 6 \\
9 \cdot 3 \\
3 \cdot 7 \\
3 \cdot 1 \\
2 \cdot 9 \\
1 \cdot 7 \\
1 \cdot 4\end{array}$ & $\begin{array}{l}(0 \cdot 8-3 \cdot 5) \\
(1 \cdot 3-7 \cdot 1) \\
(0 \cdot 2-2 \cdot 5) \\
(1 \cdot 0-3 \cdot 5) \\
(0.9-2 \cdot 5) \\
(0.8-3 \cdot 0) \\
(1 \cdot 5-55 \cdot 7) \\
(0.9-15 \cdot 1) \\
(1 \cdot 0-9 \cdot 7) \\
(1 \cdot 2-7 \cdot 2) \\
(0.6-4 \cdot 7) \\
(0.5-3 \cdot 6)\end{array}$ \\
\hline
\end{tabular}

*Odds ratios adjusted for primigravidity, prematurity, alcohol consumption, and leisure time activities (cleaning at home, gardening, outdoor activities) 
Table 7 Associations between mental retardation and occupational exposures of the father in the preconception period according to information gathered by means of a personal interview or generated by the British job exposure matrix $x^{5}\left(n=49 /\right.$ matching $^{2}$ exposures $n=30$ )

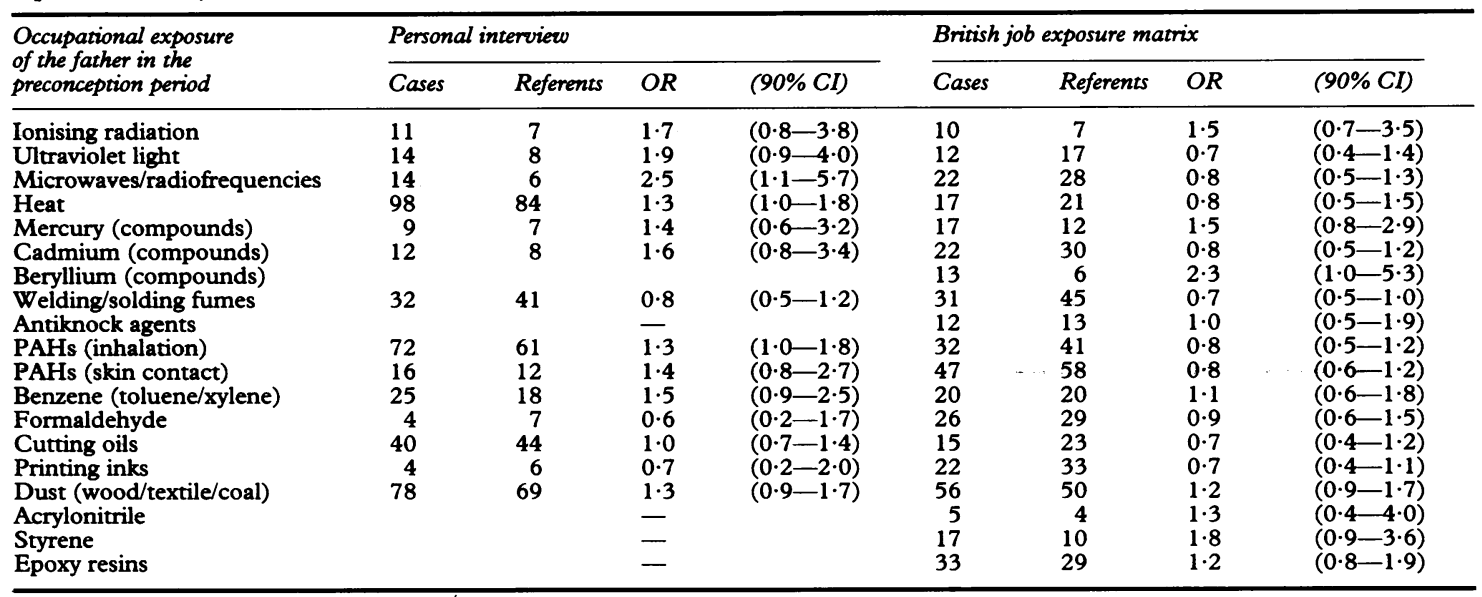

omitted from the tables when the ORs from both the interview and job exposure matrix were close to unity.

In the interview data, significantly increased ORs were found for working in a hot environment (OR $=1.3$ ) and for exposure to microwaves/radiofrequencies $(O R=2 \cdot 5)$, and exhaust fumes/polycyclic aromatic hydrocarbons (PAHs) $(\mathrm{OR}=1 \cdot 3)$. The increased $\mathrm{ORs}$ for ionising radiation $(\mathrm{OR}=1 \cdot 7)$, ultraviolet light $(O R=1 \cdot 9)$, cadmium $(O R=1 \cdot 6)$, benzene/toluene/xylene $(\mathrm{OR}=1 \cdot 5)$, chloroform ( $O R=2 \cdot 7)$, carbon disulphide $(O R=1 \cdot 8)$, and isocyanates $(O R=1.6)$ were not statistically significant (tables 7 and 8). In the British matrix, increased ORs were found for exposure to beryllium $(O R=2 \cdot 3)$ and styrene $(O R=1 \cdot 8)$. The $O R$ for welding fumes was significantly decreased (OR $=0 \cdot 7$ ). The associations found in the interview for ultraviolet light and heat were confirmed by the American matrix, which also showed a decreased OR for iron/zinc (OR $=0.7)$ and increased $O R s$ for lubricants and cutting oils $(\mathrm{OR}=2 \cdot 1)$ and pesticides $(O R=1 \cdot 4)$.

Among the exposures not generated by the matrices, working with copying machines (OR = $1 \cdot 5,90 \% \mathrm{CI} 0 \cdot 9-2 \cdot 6)$ and exposure to ultrasound (OR $=4 \cdot 9,90 \%$ CI $1 \cdot 3-17 \cdot 7$ ), acid solutions (OR $=1 \cdot 6,90 \%$ CI $0.9-2 \cdot 8)$, and chipboard $(\mathrm{OR}=1.5$, 90\% CI 0.9-2.6) should be mentioned.

\section{Discussion}

In the present study on mental retardation and parental occupation, exposure data generated by a British and an American job exposure matrix were compared with detailed occupational histories obtained by means of a personal interview with the parents, to evaluate the applicability of job exposure matrices. The agreement between the interview and job exposure matrices was low, which was caused in particular by a large number of false positive exposures generated by the matrices. In the interview data, a series of increased ORs was found for occupational exposures of the mother; a few paternal exposures were also associated with mental retardation. Analyses of the matrix data confirmed only a few of these associations and yielded hardly any increased ORs that were not found by the interview. Before conclusions are drawn, however, it is worthwhile to consider the possible flaws in the study methodology, such as selection bias and confounding, and the quality of information from the interviews as well as the properties of the job exposure matrices.

The study population was selected according to the aetiology of the handicaps. Cases were excluded whenever a cause was suspected, whereas a definite cause had been shown for all the referents, which was unrelated to the parental occupation. Case and referent parents were comparable with respect to the background variables age, education and living environment, and most lifestyle factors, in which they also resembled the general population. ${ }^{19}$ Therefore, it is unlikely that the selection of cases and referents biased the results obtained by the interview. The differences between the interview and job exposure matrices cannot be ascribed to selection bias either, as the study population was similar. All the confounders (primigravidity, complications during pregnancy, prematurity, alcohol consumption, and leisure time activities) were controlled for in the analyses of the interview as well as the job exposure matrices. 
Table 8 Associations between mental retardation and occupational exposures of the father in the preconception period according to information gathered by means of a personal interview or generated by the American job exposure matrix ${ }^{6}$ (matching exposures $n=42$ )

\begin{tabular}{|c|c|c|c|c|c|c|c|c|}
\hline \multirow{2}{*}{$\begin{array}{l}\text { Occupational exposure } \\
\text { of the father in the } \\
\text { preconception period }\end{array}$} & \multicolumn{4}{|c|}{ Personal interview } & \multicolumn{4}{|c|}{ American job exposure matrix } \\
\hline & Cases & Referents & $O R$ & $(90 \% \mathrm{CI})$ & Cases & Referents & $O R$ & $(90 \% C I)$ \\
\hline Ionising radiation & 11 & 7 & $1 \cdot 7$ & $(0.8-3.8)$ & 62 & 60 & $1 \cdot 1$ & $(0.8-1 \cdot 6)$ \\
\hline Ultraviolet light & 14 & 8 & 1.9 & $(0.9-4.0)$ & 135 & 121 & $1 \cdot 3$ & $(1 \cdot 0-1 \cdot 7)$ \\
\hline Microwaves/radiofrequencies & 14 & 6 & $2 \cdot 5$ & $(1 \cdot 1-5 \cdot 7)$ & 7 & 10 & 0.7 & $(0 \cdot 3-1 \cdot 7)$ \\
\hline Vibration & 113 & 120 & $1 \cdot 0$ & $(0 \cdot 8-1 \cdot 3)$ & & & - & \\
\hline Heat & 98 & 84 & $1 \cdot 3$ & $(1 \cdot 0-1 \cdot 8)$ & 49 & 41 & $1 \cdot 3$ & $(0.9-1.9)$ \\
\hline Mercury (compounds) & 9 & 7 & $1 \cdot 4$ & $(0 \cdot 6-3 \cdot 2)$ & 22 & 35 & 0.6 & $(0.4-1.0)$ \\
\hline Cadmium (compounds) & 12 & 8 & $1 \cdot 6$ & $(0.8-3.4)$ & 11 & 14 & 0.8 & $(0.4-1.6)$ \\
\hline Iron/zinc (compounds) & 56 & 60 & $1 \cdot 0$ & $(0.7-1.4)$ & 58 & 84 & 0.7 & $(0.5-0.9)$ \\
\hline Aluminum/magnesium (comp) & 38 & 44 & 0.9 & $(0.6-1 \cdot 3)$ & 17 & 27 & 0.6 & $(0.4-1 \cdot 1)$ \\
\hline Antiknock agents & & & - & & 60 & 51 & 0.9 & $(0.6-1 \cdot 2)$ \\
\hline Exhaust fumes & 72 & 61 & $1 \cdot 3$ & $(1 \cdot 0-1 \cdot 8)$ & 42 & 42 & $1 \cdot 1$ & $(0 \cdot 7-1 \cdot 7)$ \\
\hline Coal tar & 16 & 12 & $1 \cdot 4$ & $(0 \cdot 8-2 \cdot 7)$ & 83 & 76 & $1 \cdot 2$ & $(0.9-1.6)$ \\
\hline Naphthalene & & & - & & 6 & 9 & 0.7 & $(0.3-1 \cdot 7)$ \\
\hline Phenol/cresol & 5 & 4 & $1 \cdot 3$ & $(0.4-4 \cdot 0)$ & 28 & 33 & 0.9 & $(0.6-1.4)$ \\
\hline Benzene/toluene/xylene & 25 & 18 & $1 \cdot 5$ & $(0.9-2.5)$ & 75 & 86 & 0.9 & $(0 \cdot 7-1 \cdot 2)$ \\
\hline Chloroform & 5 & 2 & $2 \cdot 7$ & $(0.7-10 \cdot 6)$ & 13 & 12 & $1 \cdot 2$ & $(0.6-2.2)$ \\
\hline Alcohol & 26 & 21 & $1 \cdot 3$ & $(0 \cdot 8-2 \cdot 2)$ & 26 & 21 & $1 \cdot 3$ & $(0 \cdot 8-2 \cdot 2)$ \\
\hline Formaldehyde & 4 & 7 & 0.6 & $(0 \cdot 2-1 \cdot 7)$ & 8 & 11 & 0.8 & $(0.4-1.7)$ \\
\hline Ethyl ether & & & - & & 36 & 35 & $1 \cdot 1$ & $(0 \cdot 7-1 \cdot 7)$ \\
\hline Carbon disulphide & 5 & 3 & $1 \cdot 8$ & $(0.5-5.9)$ & 18 & 17 & $1 \cdot 1$ & $(0 \cdot 6-2 \cdot 0)$ \\
\hline Lubricants and cutting oils & 40 & 44 & $1 \cdot 0$ & $(0.7-1.4)$ & 10 & 5 & $2 \cdot 1$ & $(0.9-5 \cdot 3)$ \\
\hline Paint/pigments/dyes & 83 & 85 & $1 \cdot 0$ & $(0.8-1.4)$ & & & - & \\
\hline Pesticides & 31 & 26 & $1 \cdot 3$ & $(0 \cdot 8-2 \cdot 0)$ & 60 & 49 & $1 \cdot 4$ & $(1 \cdot 0-1 \cdot 9)$ \\
\hline Dust (wood/textile/coal) & 78 & 69 & $1 \cdot 3$ & $(0.9-1 \cdot 7)$ & 109 & 119 & 0.9 & $(0 \cdot 7-1 \cdot 2)$ \\
\hline Acrylonitrile & & & - & & 11 & 8 & $1 \cdot 5$ & $(0 \cdot 7-3 \cdot 2)$ \\
\hline Butadiene/styrene/chloroprene & & & - & & 11 & 14 & 0.8 & $(0.4-1.6)$ \\
\hline Isocyanates (polyurethanes) & 24 & 16 & $1 \cdot 6$ & $(0 \cdot 9-2 \cdot 8)$ & 15 & 16 & $1 \cdot 0$ & $(0.5-1.8)$ \\
\hline Vinyl chloride & & & - & & 6 & 4 & 1.6 & $(0.6-4 \cdot 6)$ \\
\hline Epoxy resins & & & - & & 64 & 70 & $1 \cdot 0$ & $(0 \cdot 7-1 \cdot 3)$ \\
\hline
\end{tabular}

In the interview, information was collected from the parents personally by skilled interviewers with a structured questionnaire. The quality of the information was satisfactory for almost all participants with regard to consistency and completeness. No differences were found between the data obtained from both parents and the data supplied by the mother only. To avoid recall bias in the interview, ${ }^{2}$ children with other congenital handicaps were chosen as referents. It was expected that the quality of the answers of case and referent parents would correspond because of the comparable emotional impact of having a handicapped child. In a validity study with colleagues as dual respondents, we have shown that this is indeed true. ${ }^{4}$ Because of the long time lag between pregnancy and interview (two to 25 years), underreporting of occupational exposures was not unlikely. ${ }^{32021}$ The occupational hygienist who checked the interviews noted remarkably good agreement, however, between the number and kind of exposures reported by the parents and those expected on the basis of the occupational title. For these reasons, the interview was considered as the gold standard of occupational exposure in this study.

The applicability of job exposure matrices for a particular study is determined by the coding scheme for occupations and industries and the input of exposures. The coding schemes of the matrices used in the present study proved to be very country specific. ${ }^{22} 23$ Some common Dutch occupations could not be accurately classified despite the detailed information from the personal occupational histories. Some occupational titles comprised a broad range of occupational activities and others were extremely detailed. Therefore, misclassification of occupation or industry almost certainly occurred, leading to misclassification of exposures. This may also be induced by the assessment of exposures in the matrix, which was inferred from job titles and industries by means of experts and textbooks instead of from actual occupational histories..$^{5-7}$ As has been shown in previous studies, ${ }^{23}$ several of the generated exposures were inappropriate for occupations in The Netherlands. Moreover, variations in the kind and level of exposure across time and place cannot be taken into account when a job exposure matrix is used..$^{22}$ As a result, serious misclassification of the exposures generated by the matrices must be borne in mind. As the level of exposure was not stated explicitly in the interviews and was therefore not considered in the analyses, misclassification in the assigned exposure grades was not an issue in this study.

Apart from misclassification problems, the specific exposure categories that have been included in 
the matrices are crucial for the applicability. The British matrix was developed for studies on occupational diseases in general with emphasis on lung diseases and cancer. ${ }^{5}$ Cancer was also the main objective of the American job exposure matrix. ${ }^{6}$ This means that, next to common occupational exposures, (suspected) carcinogens primarily make up the list of exposure items. This limits the utility in, for instance, reproductive epidemiological studies; however, a certain overlap between agents with carcinogenic and teratogenic properties is assumed. ${ }^{24}$

The mentioned limitations of job exposure matrices are reflected in the results of the present study. The measures of agreement between the interview and matrices indicated low sensitivities for the identification of risk factors for mental retardation, in accordance with studies on lung diseases. ${ }^{22}{ }^{23}$ Considering the interview as the gold standard, a high degree of misclassification on exposure was also clearly shown by the large number of false positive exposures. These findings were confirmed when the occupational exposures were evaluated separately. The prevalence of exposure was higher in the matrices than in the interview for most of the exposure items. Moreover, most increased ORs found by means of the interview could be interpreted logically, whereas those for exposures generated by the job exposure matrices could hardly be explained.

Among the mothers, the associations between mental retardation and mercury (compounds), alcohol and other solvents, and radiation were in agreement with other published information ${ }^{10}{ }^{13-17}$ and with the high risk occupations in late pregnancy (table 2). Nurses, for example, stated that they were exposed to these four agents and to hexachlorophene/phenylphenol and antibiotics. Apart from alcohol, hair cosmetics and dyes seem to be the main exposure for hairdressers. Pigments may be the causal agents in hair dyes, just like in paint and textile dust, which agrees with the increased OR for the textile industry. Work with copying machines may explain the higher risk for clerical workers through exposure to ozone, for instance. Climatic factors, such as heat, draught and lack of fresh air, were mentioned by many mothers in high risk occupations. These factors were probably associated with infections that went unnoticed, particularly in occupations that involve permanent contact with people (for example, nurses, teachers, and cashiers). This hypothesis was confirmed by the increased OR for "contact with public" in the British matrix. Otherwise, most of the associations were missed by the job exposure matrices.

As no relations were found between mental retardation and the occupational title of the father, the increased ORs found for several exposures were difficult to interpret. There was almost no agreement between the interview and either one of the two job exposure matrices. Non-ionising radiation seemed to be the most important paternal risk factor and was associated with paramedical occupations. For the other occupational exposures of the father, no conclusions can be drawn.

We can conclude that the job exposure matrices used in the present study did not offer a good alternative for the personal interview. The interview provided detailed information about the occupational exposure of the parents, which resulted in a series of increased ORs. These findings could not be explained by misclassification of exposure or other sources of bias. The results of the matrices, however, were highly conflicting and did not generate any new hypotheses about high risk exposures. On the contrary, by the sole use of the matrices almost all the observed associations between mental retardation and parental occupational exposure would have been missed. The interview data supported the hypotheses that parental exposure to (non)-ionising radiation, heavy metals, and solvents before or during pregnancy increases the risk of having a mentally retarded child. Other substances, such as hair cosmetics and dyes, paint, pigments, disinfectants and medical drugs, as well as infections through close contact with people, and work with copying machines, may be labelled as possible maternal risk factors for mental retardation. These risks were most pronounced in cases where exposure continued until late pregnancy (months 6-9).

As to the applicability of job exposure matrices in reproductive epidemiological studies in general, we can agree with preceding investigators. ${ }^{622} 23 \mathrm{Job}$ exposure matrices might be useful for explorative studies in certain situations, but because of their properties and limitations they tend to obscure real associations through severe misclassification of exposure. Therefore, they have low sensitivity for the identification of occupational risk factors for reproduction and thus limited applicability. This is particularly true when job exposure matrices are used in another country and for a purpose other than they were originally designed for. So far, personal occupational histories remain indispensible for thorough aetiological research on reproductive defects.

We owe special thanks to Ms L de Bree-Stroo for data retrieval, to Ms M Opsteeg-Vos and Ms T Reitsma-Kuil for their excellent interviewing, to $\mathrm{Ms}$ $M$ Aalbers (student), W Braun, D Heederik, and $\mathrm{H}$ Kromhout (Agricultural University, Wageningen) for their help with the job exposure matrices, and to JP Vandenbroucke and RL Zielhuis for their critical comments on the manuscript. Furthermore, we are most obliged to the Department of Paediatrics of 
the University of Nijmegen (Dr G Stoelinga), the Maartensclinic (Dr J Rosberger) and the Johanna Stichting (Dr H Vos), and to all the parents for their participation in the study.

Requests for reprints to: N Roeleveld MSc, PhD, Department of Medical Informatics and Epidemiology, University of Nijmegen, PO Box 9101, 6500 HB Nijmegen, The Netherlands.

1 Lemasters GK, Selevan SG. Types of exposure models and advantages and disadvantages of sources of exposure data for use in occupational reproductive studies. In: Lockey JE, Lemasters GK, Keye WR Jr, eds. Reproduction, the new frontier in occupational and environmental health research. New York: Alan R Liss Inc, 1984; 67-79.

2 Coughlin SS. Recall bias in epidemiologic studies. $f$ Clin Epidemiol 1990;43:87-91.

3 Baumgarten M, Siemiatycki J, Gibbs GW. Validity of work histories by interview for epidemiologic purposes. Am $\mathcal{F}$ Epidemiol 1983;118:583-91.

4 Roeleveld N, Kiemeney L, Schattenberg G, Peer P. Information bias in a case-referent study on mental retardation and parental occupation: colleagues as dual respondents. Epidemiology 1990;1:292-7.

5 Pannett B, Coggon D, Acheson ED. A job-exposure matrix for use in population based studies in England and Wales. Br F Ind Med 1985;42:777-83.

6 Hoar KH, Morrison AS, Cole PH, Silverman DT. An occupation and exposure linkage system for the study of occupational carcinogenesis. 7 Occup Med 1980;22:722-6.

7 Hoar S. Job exposure matrix methodology. f Toxicol Clin Toxicol 1984;21:9-26.

8 World Health Organisation Joint Commission on International Aspects of Mental Retardation. Mental retardation: Meeting the challenge. WHO Offset Publication; number 86. Geneva: WHO, 1986.

9 Taft LT. An overview of the etiology of mental retardation and developmental disabilities. In: McCormack MK, ed. Prevention of mental retardation and other developmental disabilities. Pediatric Habilitation. Vol 1. New York: Marcel Dekker Inc, 1980: 3-13.

10 Roeleveld N, Zielhuis GA, Gabreëls F. Occupational exposure and defects of the central nervous system in offspring: review. Br $\mathcal{F}$ Ind Med 1990;47:580-8.

11 Beattie AD, Moore MR, Goldberg A, et al. Role of chronic low-level lead exposure in the aetiology of mental retardation. Lancet 1975;i:589-92.

12 Clarkson TW, Nordberg GF, Sager PR. Reproductive and developmental toxicity of metals. Scand 7 Work Environ Health 1985;11:145-54.

13 Harada M. Congenital Minamata disease: intra-uterine methylmercury poisoning. Teratology 1978;18:285-8.

14 Chang LW, Annau Z. Developmental neuropathology and behavioral teratology of methylmercury. In: Yanai J, ed. Neurobehavioral Teratology. Amsterdam: Elsevier Science Publishers, 1984;405-32.

15 Kalter H, Warkany J. Congenital malformations: etiologic factors and their role in prevention (two parts). N Engl $f$ Med 1983;308:424-31, 491-7.

16 Mole RH. Consequences of pre-natal radiation exposure for post-natal development. A review. Int $\mathcal{f}$ Radiat Biol 1982;42:1-12

17 Otake $M$, Schull WJ. In utero exposure to A-bomb radiation and mental retardation: a reassessment. $\mathrm{Br} f$ Radiol 1984;57:409-14.

18 International Labour Office. International standard classification of occupations (revised edition, 1968). Geneva: ILO Publications, 1978.

19 Roeleveld N, Vingerhoets E, Zielhuis GA, Gabreëls F. Mental retardation associated with parental smoking and alcohol consumption before, during and after pregnancy. Preventive Medicine 1991 (in press).

20 Koskela R-S, Kolari PJ, Järvinen E, Korhonen $H$. Completeness of occupational history and occurrences of work-related diseases. Scand 7 work Environ Health 1984; 10:455-9.

21 Pershagen CT, Axelson O. A validation of questionnaire information on occupational exposure and smoking. Scand $\mathcal{f}$ Work Environ Health 1982;8:24-8.

22 Hinds MW, Kolonel LN, Lee J. Application of a job-exposure matrix to a case-control study of lung cancer. $\mathcal{f}$ Natl Cancer Inst 1985;75:193-7.

23 Heederik D, Pouwels H, Kromhout H, Kromhout D. Chronic non-specific lung disease and occupational exposures estimated by means of a job exposure matrix: the Zutphen study. Int f Epidemiol 1989;18:382-9.

24 Wilson JG. Current status of teratology. General principles and mechanisms derived from animal studies. In: Wilson JG, Fraser FC, eds. Handbook of teratology. Vol 1. New York: Plenum Press, 1977: 47-74.

Accepted 9 November 1992 